\title{
sciendo
}

Disputatio Lecture 2018

\section{Practical Identity and Duties of Love}

\author{
Berit Brogaard \\ University of Miami
}

DOI: $10.2478 /$ disp-2021-0002

BIBLID [0873-626X (2021) 60; pp. 27-50]

\begin{abstract}
This paper defends the view that we have special relationship duties that do not derive from our moral duties. Our special relationship duties, I argue, are grounded in what I call close relationships. Sharing a close relationship with another person, I suggest, requires that both people conceive of themselves as being motivated to promote the other's interests. So, staying true to oneself demands being committed to promoting the interests of those with whom we share a close relationship. Finally, I show that the proposed account of special relationship duties circumvents two problems facing self-conception accounts of special relationship duties.
\end{abstract}

\section{Keywords}

Close relationships, friendships, practical identity, romantic love, special relationship duties.

\section{Introduction}

It is widely agreed that we have duties (or obligations or responsibilities) to people with whom we share a special relationship_duties we do not have to those with whom we don't share a special relationship; e.g., Scheffler (2001). ${ }^{1}$ Special relationship duties may include duties to visit your sick mother in the hospital, co-sign on your friend's mortgage loan, bail out your brother from prison, or rescue your child from the fire before you rescue the other children. ${ }^{2}$

${ }^{1}$ I will use 'duties', 'obligations', and 'responsibilities' synonymously.

${ }^{2}$ These kinds of duties are sometimes referred to as "associative duties" (Dworkin 1986; Scheffler 2001). Associative duties comprise special relationship duties but are usually taken to have a wider scope, encompassing, for instance, duties to members of one's social or political group (Dworkin 1986: 196). Relations typically taken to create associative duties include those among partners, lovers, friends, 
The assumption that we have duties to people with whom we share certain special relationships that we do not have to those with whom we do not share them is not in dispute. What's at stake is what grounds our special relationship responsibilities. According to one view, our special relationship obligations derive from, or are subordinate to, our moral duties. According to a second view, some of our special relationship duties are non-moral duties. I will refer to the former view as "egalitarianism" and the latter as "non-egalitarianism" (Scheffler 2001). Both of these positions come in strong and moderate forms. Strong egalitarianism, as I will define it, is the view that all of our special relationship duties are, or derive from, our moral duties, whereas moderate egalitarianism is the view that our special relationship duties are subordinate to our moral duties; thus, moderate egalitarians hold that our special relationship responsibilities do not violate our moral duties. ${ }^{3,4}$

Non-egalitarianism in its most extreme form holds that relations among partners, lovers, friends, family members, roommates, neighbors, coworkers, classmates, compatriots, and members of the same sports team, union, political party, church, religion, or social identity group can be the source of special relationship duties. It is generally agreed that this form of non-egalitarianism is unsustainable. John Cottingham (1986) articulates this view as follows:

Those picked out for special treatment are specified not in terms of some descriptive (and therefore universalizable) quality or feature that they possess, but in terms of some particular relationship which they

family members, roommates, neighbors, coworkers, classmates, compatriots, and members of the same sports team, union, political party, church, religion, or social identity group (e.g., Blacks, Latinxs, Asians, or the LGBTQ+ community).

${ }^{3}$ E.g., Singer (1972), Kagan (1989), and Arneson (2016) express sympathies toward extreme egalitarianism, whereas Goodin (1985), Sadler (2006), and Abizadeh and Gilabert (2008) express sympathies toward moderate egalitarianism.

${ }^{4}$ At least some of our special responsibilities seem to derive from our secondperson epistemic duties. Thus, if we owe it to a stranger not to violate her right to epistemic justice, then we also owe it to our good friend Iris not to violate her right to epistemic injustice (see Fricker 2003, 2007, Medina 2011, 2012, 2013). So, it's a reasonable guess that egalitarians do not ultimately want to maintain that all of our special responsibilities derive from, or depend on, our moral duties. For simplicity's sake, however, I shall set aside our second-person epistemic duties. 
have to the agent. Thus, in the fire case, my decision to favour my child is based simply on the fact that she is my daughter: there is a non-eliminably particular, self-referential element in my rationale for selecting this child rather than some other. (358-9)

A less extreme form of non-egalitarianism, which I will call strong "non-egalitarianism" holds that personal relationships are the source of our special relationship duties, where mere group membership, discrete interactions with strangers, and transactional relationships do not by themselves count as personal relationships. ${ }^{5}$ In our (reciprocal) personal relationships, we relate to each other as unique individuals, which is to say, we have de re attitudes of a certain duration and frequency towards the other in the their absence, at least some of our interactions with the other are deliberate or planned, and our interactions are not primarily (directly or indirectly) transactional. Thus, being related by blood, marriage, co-ownership, workplace, address, social group, or country does not by itself rise to the level of a personal relationship. Rubbing shoulders with a stranger on the subway is not deliberate or planned, interacting primarily as hairstylist and customer is directly transactional, and interacting primarily as coworkers is indirectly transactional. Romantic relationships, friendships, and family relationships, by contrast, tend to be of a personal nature.

A more moderate form of non-egalitarianism holds that the people to whom we have special relationship responsibilities must possess some intrinsic or relational feature over and above their sharing a personal relationship with us, and that that intrinsic or relational feature justifies their being the recipients of specially favorable treatments. Moderate non-egalitarianism furthermore does not take our special relationship duties to be constrained by our moral duties. Rather, it leaves open the possibility that special relationship responsibilities can sometimes override moral duties.

In this paper, I defend a version of moderate non-egalitarianism. Our special relationship duties, I argue, are grounded in what I call "close relationships". Sharing a close relationship with another per-

\footnotetext{
${ }^{5}$ For defenses of non-egalitarianism, see e.g. Williams 1981, MacIntyre 1984, Cottingham 1986, Tamir 1993, Scheffler 1997, 2001, Jeske 1998, 2001, 2008, Keller 2006, Wallace 2010, Pismenny 2020.
} 
son, I will argue, requires conceiving of oneself as being motivated to promote the other's interests. So, staying true to oneself demands being committed to promoting the interests of those with whom one shares a close relationship. I show that the proposed account is consistent with voluntarism, the view that the source of our special relationship obligations are our own voluntary acts. Along the way, I provide arguments against egalitarianism in both its strong and moderate form and strong non-egalitarianism.

The plan for the paper is as follows. In section 2, I present three arguments against the proposal that our special relationship duties derive from, or are subordinate to, our moral duties. In section 3, I revisit Christine Korsgaard's case for the view that all duties are grounded in our practical identities but argue that because our personal relationships are not essentially linked to our practical identities, our practical identities are not a source of duties to those with whom we merely share a personal relationship. In section 4, I develop an account of close relationships that ties closeness to our practical identities. In section 5, I argue that our close relationships are a source of special relationship duties, and that these special relationship responsibilities can come into conflict with moral duties and other special relationship obligations. Finally, I show that the proposed account circumvents two problems facing self-conception accounts of special relationship duties.

\section{Amoral and immoral special relationship duties}

Egalitarians hold that our special relationship duties are the sources of, or are constrained by, our moral duties (e.g., Singer 1972, Goodin 1985, Kagan 1989, Sadler 2006, Abizadeh and Gilabert 2008, Arneson 2016). Three classes of moral duties may be taken to ground, or constrain, our special relationship obligations. One is the class of general moral duties, the duties we have to others simply by virtue of being participants in the moral community. We can take these duties to be grounded in our fundamental moral duty to respect the worthiness of the humanity that all people have in common, irrespective of their specific virtues, talents, attitudes, and choices. This is also known as the principle of respect for persons (Korsgaard 2008, Darwall 2009). This principle - which is commonly associated with 
Immanuel Kant and the ethics of The Metaphysics of Morals - renders it morally wrong to treat people merely as a means to an end. The humanity that all people share in common morally demands respecting their self-governing, autonomous, unique, private, dignified, and vulnerable personhood (Korsgaard 2008). ${ }^{6}$ By respecting others, we grant that they have fundamental liberty rights in virtue of the intrinsic worth of personhood and not merely in virtue of their utility, for example, rights to engage in self-directed behavior and to adopt and pursue their own ends, rights to minimally decent human life, and rights to be left alone and undisturbed and hide aspects of their life from publicity. Because we stand in reciprocal relations of mutual accountability to other participants in the moral community, we can expect each other to respect our fundamental rights. Those who violate our fundamental rights are eligible to negative reactive attitudes, such as blame, resentment, and indignation (Strawson 1962).

Our direct and indirect transactional relationships and the associated claims rights are a source of a second class of moral duties. Direct transactional relationships are contractual relationships, whereas indirect transactional relationships are relationships we enter into in order to fulfil our direct transactional duties. Your relationship with your landlord, your employer, the college you attend, and the general contractor you hire to build a home are examples of direct transactional relationships, whereas your relationships with your co-tenants, coworkers, college professors, and sub-contractors (e.g., carpenters, electricians, and plumbers) are examples of indirect transactional relationships. Transactional relationships create claims rights. By contrast to liberty rights, claims rights are rights that need to be fulfilled by a particular person or institution. Thus, if I hire you as a general contractor to build my home, you have a claims right to be paid for the job I hired you to do, and I have a moral duty to pay you.

A third class of moral duties are those created by promises, pledges, vows, oaths, refusals, and agreements. The latter belong to a category of speech acts of the kind John Searle (1976) calls "com-

${ }^{6}$ On vulnerability as a moral consideration, see e.g. Butler 2004, 2009, Nussbaum 2006, Mackenzie 2014. Liberty rights associated with vulnerability include the right to protection, the right to personal integrity, and the right to a minimally decent life. 
missive speech acts". When you make a commissive speech act, you commit yourself to do or not do something. Like other speech acts, commissive speech acts can be either direct or indirect. "I promise to show up by 7 p.m”. is an example of a direct commissive speech act, whereas "I will show up by 7 p.m". is an example of an indirect commissive speech act. Commissive speech acts deliberately lead other people to expect that we will behave or not behave in certain ways. This typically generates moral duties to do the things we have deliberately led them to expect we will do, except when the commissive speech act is itself immoral or it commits us to do something immoral. For example, threatening someone with a gun deliberately leads them to expect that we are prepared to shoot them, but because true treats are immoral, threatening someone with a gun does not create a moral duty to be prepared to shoot them, not even a prima facie moral duty. Likewise, promising someone to rob their neighbor's house leads them to expect that we will rob their neighbor's house, but because larceny is immoral, promising someone to commit larceny does not create a moral duty to commit larceny, not even a prima facie moral duty. However, when we perform a commissive speech act that is not itself immoral and that does not commit us to act immorally, then that creates a moral obligation to do the things we have deliberately led others to expect that we will or will not do.

It can be agreed upon by all sides that moral duties of these or similar kinds are sources of at least some of our special relationship duties. For example, because everyone has a right not to be subjected to assault, we have a moral duty not to hit those with whom we share special relationships, and because we are morally obligated to keep our promises, a fortiori we are morally obligated to keep our promises to those with whom we share special relationships.

However, the strong egalitarian makes a much stronger claim, viz., that our moral duties are the sole source of our special relationship duties. In the remainder of this section, I will provide three arguments against strong egalitarianism. My case against moderate egalitarianism turns on considerations presented in the next section (section 3).

One argument against strong egalitarianism turns on our practices of articulating our duties to those with whom we share a special relationship in order to be excused from fulfilling moral obligations 
we incurred in the past (Scheffler 1997: 195, Wallace 2012). For example, the statement in (1) below can excuse you from fulfilling an obligation to present a paper at an upcoming conference. This observation is sometimes taken to support the view that personal relationships are sources of special relationship obligations (Wallace 2012). However, it's not your mother's presence in a hospital that excuses you from fulfilling your obligation, as witnessed by the fact that (2)(4) cannot serve as excuses in spite of the fact that they entail (1). Nor is it your mother's being sick in the hospital that excuses you from fulfilling your obligation, as witnessed by the fact that (5) cannot serve as an excuse in spite of the fact that it entails (1). Rather, the reason (1) can excuse you from fulfilling your obligation is that it is understood as shorthand for something along the lines of (6) below.

(1) My mother is in the hospital.

(2) My mother is visiting a friend in the hospital.

(3) My mother is in the hospital for her yearly mammogram.

(4) My mother is in the hospital to get a tattoo removed.

(5) My mother is sick in the hospital. I hope the poison we poured in her coffee kills her.

(6) My mother is sick in the hospital, and it's in her best interest that I visit her, and it's important to me to promote her interests.

So, while our practices of articulating our duties to those with whom we share special relationships seem to reflect that not all of our special relationship duties derive from our moral duties, it does not support the strong non-egalitarian position that personal relationships are a source of our special relationship obligations.

A second argument against strong egalitarianism is a variant on Bernard Williams's (1981) famous "one thought too many" objection to Kant's requirement that we act only on maxims that can be regarded as valid for anyone similarly situated (Velleman 1999: 340). This demand seems to conflict with the idea of acting solely for reasons of 
love. Consider the following lifeboat case, which is loosely based on Williams's original (Brogaard 2021):

\section{The KantianWife}

A Kantian can save only one of several people who are drowning - all strangers except his wife. He judges that the maxim "I will prioritize saving my drowning wife over saving a drowning stranger" is universalizable, and saves his wife. However, when he tells his wife why he saved her rather than one of the strangers, she is anything but happy. She wanted to be saved out of love.

On a standard reading, Kant holds that acting rationally requires acting only after ensuring that the categorical imperative renders the act permissible. On this reading, acting for reasons of love without checking one's action for universalizability is irrational, even if doing so would have made no difference to how you acted. In our example above, the husband would have performed the same action (viz., saved his wife), if he had acted solely for reasons of love. But if he had acted solely for reasons of love, then he would have acted irrationally, as it would have been a mere happenstance that his action satisfied Kant's imperative.

One way to circumvent Williams's objection is to reject his intuition that there are situations that demand acting solely for reasons of love. Rather, it may be argued, you must always first consider whether your situation complies with Kant's categorical imperative, and if it does, only then may you choose to act for reasons of love. ${ }^{7}$ But I agree with Williams, that this proposal is absurd on its face. Morality cannot possibly demand that we stop to do ethics while our loved ones drown. A better reply to Williams is to deny that Kant thought of his categorical imperative as a decision procedure for what to do - a method of moral deliberation - rather than a method of justifying general moral principles (Stark 1997, Baron 1999).

While this suggestion circumvents Williams' "one thought too many" concern, it still does not ease the wife's concern, in the envisa-

${ }^{7}$ Velleman (1999) defends a version of this strategy, except he argues that the husband should save his wife, not for reasons of love, but for reasons of their shared history. 
ged example. The wife's disappointment arguably stems in part from the fact that her husband didn't take it to be his special responsibility to save her. This duty clearly is not a moral duty, which suggests that not all of our special relationship duties are moral duties.

A third argument against strong egalitarianism turns on the appearance that we have duties to help, say, a friend in need, even if doing so vitiates moral principles (Cocking and Kennett 2000). To establish this point, Dean Cocking and Jeanette Kennett (2000) propose to consider a case from the film Death in Brunswick. In the film, Carl accidentally stabs Mustapha, and in a panic, he reaches out to his best friend Dave, who initially suggests that Carl calls the police and explains what happened. But Carl - who has been in trouble with the law before - begs him not to, fearing he will end up in jail. Dave sees Carl's point and helps him move the body to the cemetery where he works. Dave then locates a coffin in a newly dug grave and squeezes Mustapha's corpse into it, next to the other body. When Mustapha's distressed wife and son later confront them, they say that they have no idea what happened to Mustapha.

Thus, in the process of helping Carl avoid jail, Dave commits some serious moral (and legal) wrongs: he has secretly disposed of a body, interfered with a grave, desecrated a corpse, and lied about Mustapha's death to his family. Despite his moral wrongdoing, he hasn't failed as a friend. Even if Dave's moral duties override his friendship duties, the fact that his friendship duties conflict with his moral duties shows that they don't derive from his moral duties. The envisaged case thus undermines strong egalitarianism. In light of these considerations, strong egalitarianism should be rejected. But this raises the question: what, if not our moral duties, grounds our special relationship duties? I turn to that question next.

\section{Grounding duties}

I have argued against strong egalitarianism that not all special relationship duties are moral duties. But this raises the question of what grounds these duties. As we will see, a promising approach is to take our moral duties and our special relationship duties to spring from the same source. I propose to take Christine Korsgaard's (1996) suggestion that the source of normativity is our self-conceptions as a 
starting point. In the spirit of Kant, Korsgaard argues that because we humans are self-conscious and thus have a conception of ourselves, we alone are in a position to take a step back from our most intense desire to reflect on whether we endorse that desire. If we don't endorse it, we are in a position to (freely) decide whether or not to act on the desire, ${ }^{8}$ and hence whether not our desire is a reason for us to act. A desire is a reason for us to act only if it withstands reflective scrutiny, that is, if we decide that on reflection we endorse that desire.

For Kant, deciding whether a desire is a reason to act requires determining whether acting on the desire is something we will to be law. This is Kant's categorical imperative. Unlike Kant himself, however, Korsgaard draws a distinction between Kant's categorical imperative and his moral law - the law of the kingdom of ends or republic of all rational beings. The moral law demands that we act only on maxims (i.e., desires) that "all rational beings could agree to act on together in a workable cooperative system" (1996: 99). The categorical imperative, by contrast, tells us to act on a maxim only if we will that acting on the maxim be law. Here, to "will" that something becomes law means to reflectively endorse that it becomes law. Reflective endorsement, Korsgaard argues, requires being true to how we conceive of ourselves. But, as Korsgaard notes, there are plethora of ways in which we can conceive of ourselves, for instance, we may conceive of ourselves as a citizen of the kingdom of ends, as someone's friend, lover, or child, as someone's psychiatrist, teacher, or babysitter, or as a member of a social identity group, religion, profession, or nation, or as a slave of our passions or a citizen of our own kingdom where only our own interests matter (1996: 101). Several of these ways of thinking of ourselves, Korsgaard suggests, can be understood as descriptions under which we value ourselves, find our lives to be worth living, and our actions worth undertaking. We can see these descriptions as comprising our practical identities. According to Korsgaard, each of our practical identities is a source of reasons and obligations, where obligations originate in what a given practical identity requires or prohibits. So, it's only the obligations that originate in a conception of ourselves as a citizen of the kingdom

${ }^{8}$ So, for Kant, if we act on a desire, we do so freely 
of ends that are moral. Obligations that arise from our conceptions of ourselves as a parent, friend, or lover are non-moral and need not be constrained by moral considerations. For example, your practical identity as a daughter may require you to visit your mother when she is sick, and your practical identity as a sister may require you to bail out your brother when he is in prison. When obligations that spring from the different practical identities come into conflict with each other, Korsgaard argues, the practical identities that are most important to us take priority. Korsgaard's proposal thus entails a rejection of moderate egalitarianism, the view that all our special relationship duties are constrained by our moral duties.

While Korsgaard's proposal provides a good starting point for our purposes, it does not prevent self-destructive practical identities from giving rise to special relationship duties. For example, we can have personal relationships with people that don't have our best interest at heart. If we nonetheless conceive of ourselves as their devoted friend or partner, then our practical identity as their devoted friend or partner would be a source of special relationship duties to stay devoted to them. This, however, runs counter to intuitions. Intuitively, only certain personal relationships should be constitutive of who we are and be a source of special relationship duties. In the next section, I will argue that only close relationships give rise to special relationship duties.

\section{Close relationships}

I propose that the personal relationships that matter to who we are are our close relationships. A close relationship can also be thought of as a loving or caring relationship or, in the case of friendship, a good friendship. ${ }^{9}$ I will use the adjectives 'close' 'caring', 'loving', and 'good' synonymously when they modify nouns like 'relationship' and 'friendship'.

To a first approximation, we can say that close relationships are marked by a mutual robust desire to promote the other's interests,

${ }^{9}$ While I am happy to say that close relationships are loving relationships, I do not take love to be a desire to promote the beloved's interests. In previous works, I have defended the view that love is an emotion. See e.g. Brogaard 2021. 
where a desire is robust just in case it has sufficient motivational strength and duration.

I'm going to tweak this characterization shortly. But first a word on the notion of an interest. In common parlance, our interests are those activities we take pleasure in performing. For example, if I say 'Thor's main interests are poetry and knitting', you will likely take me to mean that Thor enjoys reading poetry and knitting. But this isn't the sense of 'interest' that is relevant to our current pursuits. Rather, our interests are those states of affairs that further our overall flourishing, or well-being. Performing an unpleasant activity can thus be in our best interest by promoting our overall well-being. Colonoscopies are notoriously unpleasant, but people voluntarily submit to the invasive procedure because it may contribute to their overall well-being, which includes catching colon cancer early.

Clearly, we don't always know what other people's interests are. Suppose you are my close friend and that you want me to help you with a homework assignment, but that it's in your best interest to figure it out on your own. Suppose further that I don't know that not helping you is in your best interest and that I therefore come to your assistance. By helping you, I am thus hindering your interests without realizing it. Not all cases in which we fail to promote the other person's interests because we don't know that a particular thing is in their best interest should detract from our closeness. Whether this consequence follows depends on whether the desire is given a widescope (de re) or a narrow-scope (de dicto) reading:

On a wide-scope (de re) reading, closeness requires that there are some interests of yours $\mathrm{X}$ such that I desire to promote $\mathrm{X}$. On a narrow-scope (de dicto) reading, closeness requires that I desire to promote your interests $\mathrm{X}$, whatever they are. Closeness requires a de dicto desire to promote each other's interests. Closeness thus doesn't require knowing each and every interest of the other person. In some cases, however, closeness may require knowing the other person's interests, viz., when not knowing has serious consequences and a reasonable person would have known.

Our initial characterization of closeness is a good first approximation, but it needs tweaking. If close relationships are marked by a mutual robust desire to promote the other person's interests, many relationships that are naturally thought of as close are not all that 
close after all. Infants, for example, have a highly diminished capacity for forming desires to promote other people's interests. So, if we take our initial characterization at face value, parent-infant relationships would lack closeness. So would our relationships with severely dement relatives or gravely disabled friends or family members. To avoid these undesirable outcomes, let's stipulate that a capable adult can have close relationships with people with a diminished capacity for forming robust desires to promote other people's interests, despite the lack of reciprocity. This tweak is in line with the idea that a close relationship can be thought of as a loving or caring relationship.

Another issue with our initial characterization is that, as it stands, a personal relationship can be close even if one or both people are unaware of the other person's desire to promote their interests. A relationship between capable adults can be close only if the reciprocity of their desire to promote each other's interests is shared knowledge between them. Further, as Mark Alfano (2016: 188) has argued, the shared knowledge requirement is not satisfied by each person obtaining the information about the other person from a third party. The shared knowledge must be based, at least in part, on first-person evidence.

Our initial characterization of closeness faces a more serious problem. It entails that you and your enemy could harbor a mutual desire to promote each other's interests as a result of coercion by a third party. Say a psychopath is threatening to shoot both of you if you don't do your best to further each other's interests. As you don't want to die, you go out of your way to promote each other's interests. Yet this doesn't make you and your enemy close friends.

The general concern here is that the desire must be your own, not someone else's. I propose to address this issue by requiring that the desire to promote the other person's interests be grounded in a matching core value (Brogaard 2020: ch. 2). Your core values are the values that matter to who you are-your self or identity. I value spending time with my daughter, and I value having vanilla ice cream for dessert. Although I can clearly exercise agency around vanilla ice cream, for example, by freely choosing to have it for dessert, being able to make this choice is not important to who I am. So, unlike being able to spend time with my daughter, being able to have vanilla ice cream for dessert is not among my core values. 
This requirement on closeness makes the notion closely bound up with a valuational account of the self (or a person's identity) along the lines of the account of agency advanced by John Doris (2015) and others. ${ }^{10}$ Our core values, we can say, are (partly) constitutive of our "selves". You assert your "self" when you perform an action that is an expression of your core values.

The objects of our core values range from what we already have or do, such as our ability to spend time with friends or exercise our rights to life, liberty, and the pursuit of happiness, to what we want to do or have in the future, such as getting a professional degree, having children, or traveling around the world. Although we are not always aware of what our core values are or what place they occupy in our hierarchy of values, they often reveal themselves in the stories we tell when asked to explain or defend ourselves. For example, if asked why I quit smoking, I may refer to the evidential link between smoking and lung cancer, which reveals that staying healthy is among my core values.

Doris suggests irreplaceability as a criterion for determining whether you truly value something, or whether it is merely hard to resist it or a convenient way of satisfying some general need. ${ }^{11}$ As he puts it:

If the object of desiring can be replaced without loss - if life can go on pretty much as it did - then that object is not an object of value. [...] Significant human relationships [...] aren't supposed to be so easily interchangeable: the jilted and bereaved may learn to love again, but some of what they lose may seem quite irreplaceable. The non-fungibility requirement could also be erected as a bulwark against the somewhat unattractive thought that "mere needs" are values. If alternate modes of nutrition were readily available to humans, it might be that people could forgo eating with no loss; eating is the object of desire, yet doesn't have the "specialness" associated with value. (That gourmets, gourmands, and other foodies could not switch without loss makes the point; they

${ }^{10}$ Doris (2015) is mostly concerned with a valuational account of (morally responsible) agency, but develops a valuational account of the self in Chapter 8 . Watson (1996), famously, distinguishes between responsibility as attributability and responsibility as accountability (see also Watson 1975). However, modern versions of attributionism, like Doris', maintain that attributability (or answerability) is the only notion of responsibility we need (see also Scanlon 2008, 2013, Smith 2012, 2015, Talbert 2017).

${ }^{11}$ For an argument for the view that irreplaceability is a central feature of value, see also Brogaard (2015). 
do value eating.) In the end, a mere needs exclusion might not be mandatory; in conditions of scarcity, the objects associated with mere needs can start to seem pretty special. (Doris 2015: 28)

Although Doris doesn't employ the notion of a core value, what he says here seems to be more pertinent to core values than "trivial" values. Suppose you are hungry and heat some instant Mac and Cheese in the microwave. Even though being able to satisfy your need for food is among your core values, eating Mac and Cheese is not, as some other food could easily have satisfied your need. Or suppose you have an overpowering desire for sex and have a one-night stand with someone you right-swiped on Tinder. Although being able to meet your desire for sex may be among your core values, having sex with your one-night stand is not, as someone else could have satisfied your desire.

Our core values do not stay the same over time. Our core values change as our priorities change. This can be due to a situationally determined change to our personality or character. If you become more introverted, for example, then spending time on your own may become more important to who you are. But changes in our core values can also be the product of what I will call a "value adaptation", that is, an adaptation of our core values to fit the limitations of our circumstances. Say having children as soon as you feel financially secure has been one of your priorities in life for years. But time passes, and eventually your chances of becoming pregnant or adopting a child look slimmer and slimmer, until one day it dawns on you that perhaps becoming a parent isn't all that important to you after all. Such radical shifts in our core values reflect our ability to adapt to our situation. People whose core values are shaped by their circumstances are more likely to be happy with what they have than those who hold dear an unachievable childhood dream.

Value adaptation is akin to what is known as "preference adaptation" (see e.g., Bruckner 2009, Beach 2015). Sour grapes is a prime example of the latter. In the ancient Greek storyteller Aesop's renowned fable The Fox and the Grapes, from which the expression "sour grapes" originated, a fox finds himself unable to reach the sweet, juicy grapes, which he much prefers to the strawberries that are easily accessible to him. To cope with his frustration, the fox chooses to 
conceive of the sweet, juicy grapes as sour and distasteful, and on one interpretation of the fable, this change of mindset alters his preferences.

Whether preference adaptation is rational, for example, by being conducive to your overall well-being, has been the subject of substantial debate (see e.g., Sen 1977, Elster 1983, Bovens 1992, Nussbaum 2001, Pettit 2006, Baber 2007, Barnes 2007, Bruckner 2009, Beach 2015). Elizabeth Barnes (2015) discusses the Stockholm Syndrome as an example of preference adaptation that is widely agreed to be irrational:

[I]n the phenomenon known as Stockholm syndrome, victims of kidnapping or hostage-taking come to prefer being kidnapped - they come to believe that their kidnapper is really on a noble mission, and has rescued them, and that their kidnapping is thus of great benefit to them, etc. It's fairly easy to see how beliefs and preferences such as this could arise. The kidnap victim is put in a traumatic situation from which they see no possibility of escape, so simply in order to cope they (subconsciously or otherwise) lose the desire to escape. Such coping mechanisms may well be an admirable facet of human psychology, but we'd be very reluctant to say that the preferences of a person with Stockholm syndrome are rational, or serve as evidence that being a kidnap victim is a good way to live. (Barnes 2015: 127)

Fans of Álex Pina's television show La Casa de Papel (English title: Money Heist) (2017-present) may take issue with this assessment of preference adaptation in the case of Stockholm syndrome, as one of the hostesses appears to make the right choice in Season 1 when she cuts her ties to her pathetic coworker and joins the kidnappers. But perhaps this is not a genuine case of Stockholm Syndrome.

A less controversial case of irrational preference adaptation is that of an abused woman who comes to prefer to stay with her spouse because she depends on him financially. But other cases are not as easily settled. For example, disabled individuals often sincerely assert that they prefer to have their disability to not having it. On the face of it, this may seem to be a blatant case of self-deception. But Barnes (2015) makes a convincing case for not dismissing the disabilitypositive testimony of disabled people up front. Doing so would be an instance of epistemic injustice, in Miranda Fricker's (2003, 2007) sense.

Parallel questions of rationality can be asked about adaptive core 
values. Is it rational to downgrade a core value to avoid regret, disappointment, or suffering? This is not the time or place to address this issue. Suffice it to say that I suspect that value adaptations can be rational when they are in your best interest and are not mere tools for increasing your short-term happiness.

Our final account of a reciprocal close relationship can be cast as follows.

Reciprocal Close (or Loving) Relationship

A personal relationship between two capable adults is close, or loving, just when:

It is common knowledge between them that they both have a de dicto, robust desire grounded in a matching core value to promote each other's interests.

A question here arises how closeness is affected by weakness of will (akrasia), cases where we succumb to desires against our better judgment. When in the grip of weakness of will, we often prioritize purely selfish pleasure over promoting other people's interests. Say you know that keeping your dinner date with your friend Vera is important to her. Yet overpowered by weakness of will, you cancel last minute, so you can stay on the couch and watch television. Your weakness of will chips away at the closeness of your friendship with Vera, but does it compromise closeness altogether?

The answer is no. The occasional bout of weakness of will does not compromise closeness altogether, as long as we don't make a habit out of it. The reason for this is that a relationship can be close without being perfectly close. Unlike pregnancies, college degrees, and electoral wins, closeness is not an on-off matter but comes in degrees. This is witnessed by expressions such as those in (7)-(13) below:

(7) Cicely is Newell's closest friend.

(8) Harlan is equally close with all of his siblings.

(9) Our friendship hasn't been very close the past few weeks.

(10) I feel our marriage is closer than it has ever been. 
(11) Your parents' relationship would have been closer if your mom hadn't cheated on your dad.

(12) Millicent is not as close with her coworkers as she would like to be.

(13) Henrietta and Sumner's relationship is close for a relationship between ex-lovers.

Adjectives that admit of degrees are also known as "gradable adjectives". Familiar examples of gradable adjectives are 'extravagant', 'rich', 'large', 'frightened', 'honest', and 'trustworthy'. A home that would be extravagant if located in Camden, New Jersey, would probably not be extravagant if located on Fisher Island in Miami.

The question is what it takes for one relationship to be closer than another. Take my parental relationship with my teenage daughter Becky and my collegial relationship with my coworker Risto. To say that my relationship with Becky is closer than my relationship with Risto is not to say that Becky and I desire promoting each other's interests with more fervor than Risto and I do, because the felt intensity of desires can vary for reasons quite irrelevant to the question of closeness, and most of the time desires operate below the level of conscious awareness and therefore lack any felt intensity. Nor does it mean that Becky and I desire to promote a higher quantity of each other's interests than Risto and I do, because even if Risto and I aren't as close as my daughter and I, we still have a de dicto desire to promote each other's interests, period, not half of them, or one-third.

Rather, when we speak of differences in closeness, we make reference to our internal hierarchy of core values and matching desires. If it isn't practically feasible for me to promote both my daughter's and my colleague's interests, which — we can assume - are of equal importance, and I act on my value priorities, then I choose to prioritize doing what's in my daughter's interest. Say Becky's swim meet is scheduled to take place at the same time as Risto's book signing, that Becky and Risto both have an interest in me attending their events, and that their interests are comparable in importance. In the envisaged scenario, I am off to the swim meet, because when forced to choose, I prioritize Becky's interests over Risto's, even though 
promoting Risto's interests is also a core value of mine.

A relationship can be close simpliciter, even if it is not perfectly close. Closeness merely requires that the mutual desire to promote one another's interests surpasses a certain threshold. Two individuals who differ in height can both correctly be said to be tall. Similarly, two relationships that aren't equally close can both accurately be said to be close, period. How tall a person needs to be to count as tall depends on a comparison class for tallness. At six feet six inches, Michael Jordan is tall for an American man but not for an NBA basketball player. Likewise, how close a relationship must be to count as close, period, depends on the comparison class for closeness. In contemporary Western cultures, for example, younger people in long-term romantic relationships often seem to aim to be closer and better friends with their romantic partner than they are with their close (Platonic) friends. If this is true, then two people's long-term romantic relationship could be close for a close friendship but not for a long-term romantic relationship.

\section{Practical identities and duties of loving relationships}

We are now in a position to explain how close relationships can be a source of special relationship duties. As we have seen, promoting the interests of the people we are close with is among our core values. As our core values are partially constitutive of our core practical identities, our close relationships are partially constitutive of our core practical identities. Now, as noted earlier, staying true to our practical identities demands certain actions and prohibits others. For example, if you conceive of yourself as a person with integrity, then staying true to your practical identity prohibits you from acting only in your own interest. Acting only in your own interest chips away at your practical identity and will eventually destroy you. Similarly, if you conceive of yourself as being motivated to promote the interests of a person you are close with, staying true to yourself demands that you are motivated to promote their interests. So, if you know that it is in your close friend's interest to visit her in the hospital, then staying true to your practical identity demands that you visit her in the hospital. So, you have a special relationship duty to visit your close friend in the hospital. As argued earlier, special relationship duties 
can come into conflict both with other special relationship duties or moral duties, and practical reason cannot always resolve such conflicts. If you have a special relationship duty to visit your close friend in the hospital and also have a special relationship duty to visit your child in the hospital but the two hospitals are separated by thousands of miles, your duties conflict with each other. But if your child's interests take priority over your friend's, then your duty to visit your child overrides your duty to visit your friend.

One advantage of the proposed account is that it avoids the main objections to accounts that ground some of our special relationship duties in our self-conceptions. According to Wallace (2012), attempting to ground our duties in our self-conceptions makes it impossible to explain what it means to violate a special relationship duty you recognize you have. If you recognize you have a duty to a person, yet you decide not to fulfil it, then that shows that complying with this obligation is not among those things that are most important to who you are. So, he argues, the self-conception view is unable to explain how we can violate special relationship duties we recognize we have. Wallace acknowledges that the practical identity account can accommodate cases in which we violate a special relationship obligation because this duty is incompatible with another duty that has even greater significance to our practical identity than the first. However, he argues, not all of our failures to meet our special relationship obligations are of this kind.

My proposed account provides a natural reply to this objection. As we have seen, our special relationship duties are duties to people we are in close, or loving, relationships with. This account of close relationships entails that promoting the interests of those we are close with is among our core values. Staying true to our core values thus requires being motivated to promote the interests of those we are close with. Wallace is right, of course, that if you tend not to be motivated to promote the interests of a particular person, then that shows that that person isn't all that important to you. But this is not a case in which you recognize that you have certain special relationship duties yet fail to fulfil them. Rather, it's a case in which your relationship with that person is not very close after all.

Furthermore, on the proposed account, 'close' is a gradable adjective, which means that closeness comes in degrees. Even so, a re- 
lationship can be close simpliciter, even if it is not perfectly close. Closeness merely requires that the mutual desire to promote one another's interests surpasses a certain threshold.

So, while failures to comply with our special relationship duties you recognize you have chips away at your closeness, infrequent and fairly inconsequential failures do not entail that the other person's interests don't matter that much to you, or that you are not close with that person after all.

A further advantage of the proposed account is that it avoids the unwelcome implication that self-destructive practical identities give rise to special relationship duties. As we have seen, Korsgaard's account of special relationship duties is vulnerable to this problem. The problem arises, because we can have personal relationships with people who don't have our best interest at heart. So, if we conceive of ourselves as their devoted friend or partner, then our practical identity gives rise to a duty to stay devoted to them. On my account, only close relationships are a source of sui generis special relationship duties. As relationships with people who don't have our best interest at heart fail to be close, such relationships do not give rise to special relationship duties to stay devoted to them.

\section{Conclusion}

In this paper, I have defended the view that we have special relationship responsibilities that do not derive from our moral duties. Our special relationship duties, I have argued, derive from relationships of love, or what I call "close relationships". As we have seen, being close with another person requires that both people conceive of themselves as being motivated to promote the other person's interests. So, staying true to ourselves demands being motivated to promote the interests of the people with whom we share close relationships. I have furthermore shown that the proposed account avoids various pitfalls to self-conception accounts of special relationship duties. ${ }^{12}$

\footnotetext{
${ }^{12}$ For valuable comments on a previous version of this paper, I am grateful to Tim Bayne, Arina Pismenny, Katrien Schaubroeck, Michael Slote and an audience at the Disputatio Lecture/keynote address at Encontro Nacional de Filosofia Analítica 7 (ENFA 7), Lisbon, Portugal, September 13-5, 2018, organized by the
} 


\section{Berit Brogaard \\ University of Miami \\ Department of Philosophy \\ 1252 Memorial Drive \\ Ashe Administration Bldg \#721 \\ Coral Gables, FL 33124 USA \\ brit@miami.edu}

\section{References}

Abizadeh, Abizadeh and Gilabert, Pablo. 2008. Is there a genuine tension between cosmopolitan egalitarianism and special responsibilities? Philosophical Studies, 138(3): 349-65.

Alfano, Mark. 2016. Friendship and the structure of trust. In From Personality to Virtue, Alberto Masala and Jonathan Webber (eds.). Oxford: Oxford University Press, 186-206.

Arneson, Richard J. 2016. Extreme cosmopolitanisms defended. Critical Review of International Social and Political Philosophy, 19(5): 555-73.

Baber, Harriet E. 2007. Adaptive preferences. Social Theory and Practice, 33(1): $105-26$.

Barnes, Elizabeth. 2007. Disability and adaptive preference. Philosophical Perspectives, 23(1): 1-22.

Barnes, Elizabeth. 2016. The Minority Body:A Theory of Disability. New York: Oxford University Press.

Baron, Marcia. 1991. Impartiality and friendship. Ethics, 101(4): 836-57.

Beach, Sarah. 2015. Adaptive Preferences Are Not Irrational. M.A. thesis, Department of Philosophy, University of Missouri, St. Louis.

Bovens, Luc. 1992. Sour grapes and character planning. Journal of Philosophy, 89(2): 57-78

Brogaard, Berit 2015. On Romantic Love, New York: Oxford University Press.

Brogaard, Berit. 2020. Hatred: Understanding Our Most Dangerous Emotion. New York: Oxford University Press.

Brogaard, Berit. 2021. Romantic Love and Friendship Love. In D. Jeske (ed.), Routledge Handbook of the Philosophy of Friendship, Routledge. In Press.

Bruckner, Donald. 2009. In defense of adaptive preferences. Philosophical Studies, 142(3): 307-24.

Butler, Judith. 2004. Precarious Life: The Powers of Mourning and Violence. Verso: London.

Butler, Judith. 2009. Frames of War:When is Life Grievable? Verso: London.

Cocking, Dean and Kennett, Jeanette. 2000. Friendship and moral danger. The Journal of Philosophy, 97, 5: 278-96.

Cottingham, John. 1986. Partiality, favouritism and morality. The Philosophical Quarterly, 36(144): 357-73.

Darwall, Stephen. 2009. The Second-Person Standpoint: Morality, Respect, and Accountability. Cambridge, MA: Harvard University Press.

Doris, John. 2015. Talking to Our Selves: Reflection, Ignorance, and Agency. Oxford: Oxford University Press.

Dworkin, Ronald. 1986. Law's Empire. Cambridge, Mass.: Harvard University Press.

Eekelaar, John. 1991. Are parents morally obliged to care for their children? Journal

Portuguese Society for Analytic Philosophy (SPFA). 
of Legal Studies, 11(3): 340-53.

Elster, Jon. 1983. Sour Grapes: Studies in the Subversion of Rationality. Cambridge: Cambridge University Press.

Fricker, Miranda. 2003. Epistemic injustice and a role for virtue in the politics of knowing. Metaphilosophy, 34(1-2): 154-73.

Fricker, Miranda. 2007. Epistemic Injustice: Power and the Ethics of Knowing. Oxford: Oxford University Press.

Goodin, Robert E. 1985. Protecting the Vulnerable. Chicago: University of Chicago Press.

Jeske, Diane. 1998. Families, Friends, and Special Obligations. Canadian Journal of Philosophy, 28: 527-55.

Jeske, Diane. 2001. Friendship and Reasons of Intimacy. Philosophy and Phenomenological Research, 63(2): 329-46.

Jeske, Diane. 2008. Rationality and Moral Theory: How Intimacy Generates Reasons. Routledge.

Kagan, Shelly. 1989. The Limits of Morality. New York: Oxford University Press.

Kant, Immanuel. 1797. Die metaphysik der sitten, translated as "The metaphysics of morals" (MM), in Immanuel Kant Practical Philosophy, Mary Gregor (trans. and ed.). New York: Cambridge University Press, 1996.

Keller, Simon. 2006. Four theories of filial duty. The Philosophical Quarterly, 56(223): 254-74.

Korsgaard, Christine. 1996. The Sources of Normativity. Cambridge: Cambridge University Press.

Korsgaard, Christine. 2008. The Constitution of Agency: Essays on Practical Reason and Moral Psychology, Oxford: Oxford University Press.

LaFollette, Hugh. 1996. Personal Relationships: Love, Identity, and Morality. Cambridge, Mass.: Blackwell.

MacIntyre, Alasdair. 1984. After Virtue. Notre Dame, Ind.: Notre Dame University Press.

Mackenzie, Catriona. 2014. The importance of relational autonomy and capabilities for an ethics of vulnerability. In Vulnerability: New Essays in Ethics and Feminist Philosophy, Catriona Mackenzie, Wendy Rogers and Susan Dodds (eds.).New York: Oxford University Press, 33-59.

Medina, José. 2011. The relevance of credibility excess in a proportional view of epistemic injustice: differential epistemic authority and the social imaginary. Social Epistemology, 25(1): 15-35.

Medina, José. 2012. Hermeneutical injustice and polyphonic contextualism: social silences and shared hermeneutical responsibilities. Social Epistemology, 26(2): 201-20.

Medina, José. 2013. The Epistemology of Resistance: Gender and Racial Oppression, Epistemic Injustice, and Resistant Imaginations. Oxford: Oxford University Press.

Nussbaum, Martha. 2006. Frontiers of Justice: Disability, Nationality, Species Membership. Cambridge, MA: Harvard University Press.

Pettit, Philip. 2006. Preference, deliberation, and satisfaction. In S. Olsaretti (ed.), Preferences andWellbeing. Cambridge: Cambridge University Press: 131-53.

Pismenny, Arina. 2020. The amorality of romantic love. In Love, Justice, and Autonomy: Philosophical Perspectives, Rachel Fedock, Michael Kühler and Raja Rosenhagen (eds.). Routledge: 23-42.

Sadler, Brook J. 2006. Love, friendship, morality. Philosophical Forum, 37(3): 24363.

Scanlon, Thomas M. 2008. Moral Dimensions: Permissibility, Meaning, and Blame. Cambridge, MA: Harvard University Press.

Scanlon, Thomas M. 2013. Giving desert its due. Philosophical Explorations, 16(2): 101-16. 
Scheffler, S. 1997. Relationships and responsibilities. Philosophy and Public Affairs, 26: 189-209.

Scheffler, Samuel. 2001. Boundaries and Allegiances. Problems of Justice and Responsibility in Liberal Thought. Oxford: Oxford University Press.

Searle, John. 1976. A classification of illocutionary acts. Language in Society, 5(1): $1-23$.

Sen, Amartya K. 1977. Rational fools. Philosophy and Public Affairs, 6(4): 317-44.

Singer, Peter. 1972. Famine, affluence and morality. Philosophy \& Public Affairs, 1(3), $229-43$.

Smith, Angela M. (2012). Attributability, answerability, and accountability: in defense of a unified account. Ethics, 122(3): 575-89.

Smith, Angela M. 2015. Responsibility as Answerability. Inquiry, 58(2): 99-126.

Stark, Cynthia. 1997. Decision procedures, standards of rightness, and impartiality. Nous, 31(4): 478-95.

Strawson, Peter. 1962. Freedom and resentment. Proceedings of the British Academy, 48 (1962), reprinted in FreeWill, ed. G. Watson, New York: Oxford University Press, 1982: 59-80.

Talbert, Matthew. 2017. Omission and attribution error. In The Ethics and Law of Omissions, Dana Kay Nelkin and Samuel C. Rickless (eds.). New York: Oxford University Press, 17-35.

Tamir, Yuli. 1993. Liberal Nationalism. Princeton, N.J.: Princeton University Press.

Taylor, Erin. 2013. A new conventionalist theory of promising. Australasian Journal of Philosophy, 91: 667-82.

Velleman, J. David. 1999. Love as a moral emotion. Ethics, 109(2): 338-74.

Wallace, Jay R. 2012. Duties of love. Proceedings of the Aristotelian Society, 86: 17598.

Watson, Gary. 1975. Free agency. Journal of Philosophy, 72: 205-20.

Watson, Gary. 1996. Two faces of responsibility. Philosophical Topics, 24: 227-24.

Wellman, Christopher Heath. 2000. Relational facts in liberal political theory: is there magic in the pronoun 'My'? Ethics, 110(3): 537-62.

Williams, Bernard. 1981. Persons, character, and morality. In Moral Luck: Philosophical Papers 1973-1980, James Rachels (ed.). Cambridge: Cambridge University Press. 